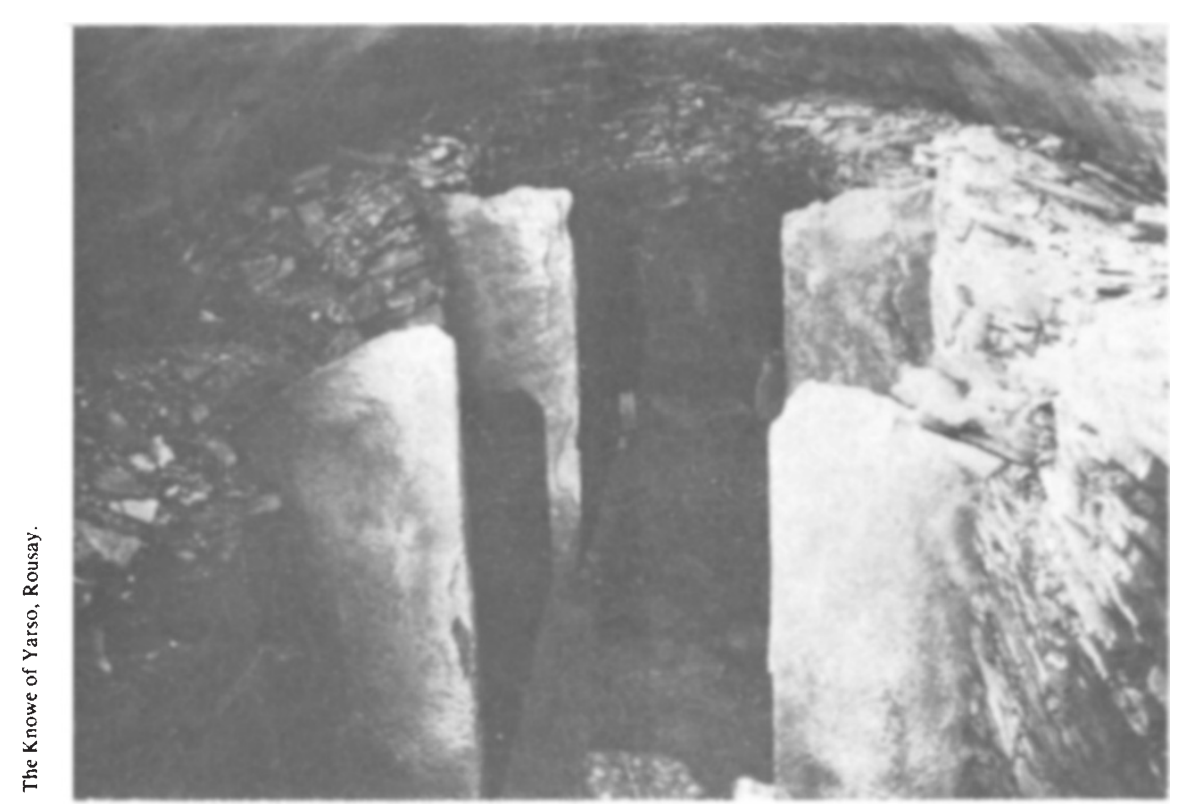

Quanterness is an architecturally iophisticated tomb and its period of use vas determined by radiocarbon neasurements to between about 3200 and $500 \mathrm{BC}$. (This itself is important as it shows cearly that the tomb is relatively late in the Neolithic period and in the Orkney series, refuting again the old diffusionist theories which demanded that the most sophisticated buildings were built first, by the original skilled colonists.) The number of individuals buried collectively generation after generation over a period of $550 \pm 180$ years - in this great roofed stone vault was estimated from the thousands of disarticulated human bones recovered to be about 400 . Both sexes and most age groups were represented, and the conclusion drawn is that all the members of a small farming community of 13-20 people were buried in the cairn.

These results, and those of the many other detailed researches carried out, form a landmark in our understanding of Orcadian Neolithic society - a mass of hard evidence which will provide a minimum standard for all future work. My only doubts concern some of the conclusions drawn from the data, particularly the failure to consider in any way - even simply to dismiss it - the alternative social interpretation of these cairns. This, argued in some detail in my book The Megalith Builders (reviewed in Nature 270, 644; 1977), suggests that the people buried in the cairns could have been the members of a non-farming section of the Neolithic population, most probably of religious orders which were linked genetically and by shared architectural and funerary traditions to the other cairn builders all over Atlantic Europe. The work at Quanterness has not disproved this interpretation unless this is considered to have been achieved by the author firmly looking the other way.

Euan W. MacKie is Assistant Keeper of Archaeology and Anthropology in the Hunterian Museum, University of Glasgow, $U K$.

\section{Immortalized in a}

\section{virus}

\section{D.H. Watson}

The Epstein-Barr Virus. Edited by M.A. Epsiein and B.G. Achong. Pp.459. (Springer: Berlin, Heidelberg and New York, 1979.) $£ 34.50$.

EPSTEIN-BARR (EB) virus was discovered in 1964 by the two workers immortalized in its name; they identified particles with the characteristic morphology of the herpesvirus family in lymphoblasts cultured from a lymphoma of a type first described in African children by Burkitt in 1958. The first chapter in this volume is an account by Epstein and Achong of this early work in which Epstein's inspiration was to examine cells cultured from the tumour after an earlier fruitless search in biopsy cells.

Since 1964 a formidable body of published work has been amassed by workers from a wide variety of disciplines using an impressive array of biochemical and biological techniques. The remaining articles in this volume, written by a number of those who have made notable contributions, summarize and review progress since 1964 .

Serological studies played an important initial role, and an early chapter by Ernberg and Klein is appropriately devoted to an account of EB antigens. This sets the stage for a description by the Henles of their notable serological studies, which not only identified $\mathrm{EB}$ virus as distinct from other herpesviruses but most unexpectedly showed that the virus was ubiquitous, often occurring in leukocytes of healthy donors in many parts of the world. This led to the link between the virus and infectious mononucleosis and also with a second rare malignancy, nasopharyngeal carcinoma. Plainly the major stumbling block was the lack of a unique or even consistent relationship of the virus to the malignant conditions.

Molecular hybridization studies, excellently described in articles by Pagano and Shaw and by zur Hausen showed, however, that virtually all nasopharyngeal carcinomas and African (if not American) Burkitt lymphomas contained virus DNA.

There still remained the difficulty of explaining why such a widely distributed virus apparently produced tumours in restricted geographical areas. Burkitt himself suggested that a malarial co-factor might account for the lymphoma but although, as indicated in a later chapter by Epstein, there is supporting evidence for this idea, it would seem that it cannot be a unique co-factor given the comparative rarity of the lymphoma, even in its favoured locale, in doubly infected individuals. Others have argued for strain variations in the virus and this is discussed in the chapter by Pagano and Shaw as well as by Miller.

A further twist to the tale is provided by the recognition that the virus DNA may sometimes exist in the cell in a nonintegrated ('episomal') form and at other times be integrated as described here by Adams. He, like Pagano and Shaw, envisages the rare change to malignant transformation from non-malignant proliferation as being mediated by insertion and operation of transforming sequences.

The other chapters are equally absorbing, dealing with aspects as varied as the recent IARC prospective seroepidemiological survey (de Thé; see also Nature 274, 756; 1978), prospects for vaccine control (Epstein), and comparative studies on oncogenic herpesviruses (Deinhardt) - to make what must in the space available be an arbitrary selection.

The volume will be useful to those from many disciplines in which EB virus has become important, in providing them with a useful statement of the current situation. Even those directly involved in the large numbers of publications on the virus will welcome the presentation in one place of such a wide-ranging survey.

D.H. Watson is Professor of General Microbiology and Head of the Department of Microbiology, University of Leeds, UK. 